\title{
Organizational Commitment in Sports Clubs
}

\author{
Serdar Samur ${ }^{1}$, Kubilay Çimen², Yunus Emre Büyükbasmacı ${ }^{2}$ \\ ${ }^{1} 397265^{\text {th }}$ Street, Woodside, NY, USA \\ ${ }^{2}$ Gelişim Üniversity, Physical Education and Sports Faculty, Istanbul, Turkey \\ Correspondence: Serdar Samur, $397265^{\text {th }}$ Street, Woodside, NY, USA.
}

$\begin{array}{lcc}\text { Received: July 1, } 2019 & \text { Accepted: July 22, } 2019 & \text { Online Published: July 24, } 2019 \\ \text { doi:10.11114/jets.v7i10.4400 } & \text { URL: https://doi.org/10.11114/jets.v7i10.4400 }\end{array}$

\begin{abstract}
It is thought that the sustainability of organizations is closely related to the fact that management levels have up-to-date knowledge specific to their respective fields and their ability to conduct their activities in the best possible way. It is believed that what creates the power of this focal point is the sense of belonging to the institutions. The aim of this study is to determine the level of organizational commitment of managers in sports clubs through seven different variables. In this study, the Meyer-Allen (1984) organizational commitment scale was used. The translation of this scale was compared to several scale translations, and no difference in meaning was observed. The scale consists of 18 questions with three sub-dimensions, namely emotional commitment, continuity dependence, and normative commitment. Questions 1-6 were related to emotional commitment, 7-12 dealt with continuation commitment, and 13-18 dealt with normative commitment. The scale is structured according to 5-point Likert scale. While preparing the personal information, support was provided by psychosocial academicians of sports. The study sample involved eleven sport managers from the Super League clubs, eleven from the first league teams, nine from the second league teams, nine from the third league teams, fifteen from the Regional Amateur League (RAL) league teams, and nineteen from the amateur sports clubs. Thus, a total of 74 sports managers participated in the survey. The surveys were constructed in the sports club buildings and in the presence of the managers. The questionnaires were conducted by the footballers who were serving in the sampled clubs. The SPSS 21 package program was used to analyze the data obtained. The Explore test, Mann-Whitney U test, and the Kruskal-Wallis test were employed for the analyses of the variables. At the end of these analyses it is understood that the age of the employees in the clubs, the term of duty, the wages they receive and the age of the club do not significantly affect the level of organizational commitment. Besides, It has been seen that the league, where the club is located, the level of duty of the managers, and having a regular time in the club affect the level of organizational commitment.
\end{abstract}

Keywords: organizational commitment, sports clubs, sports manager, sustainability

\section{Introduction}

\subsection{Introduction the Problem}

The survival of organizations is closely related to their managers' focus on their specific knowledge, skills, and work. As in many institutions and organizations, the level of organizational commitment of the managers in sports clubs is important for the success of the club.

The main criterion for the definition of success of clubs is that they have sufficient economic resources to sustain their activities. The most important economic resources of the clubs are the transfer of young players raised in football academies with high transfer prices and the success of professional teams in national and international arenas. While this success is the most important input that provides money to the existing resources, it is an important interface that increases the brand value of the club and provides access to sponsors (Samur, 2018).

It is thought that the most important element of this success is the presence of the people who created it. It is up to many factors to maximize their potential in an environment where these people feel happy. It is believed that the most important of these is the sense of belonging to professional clubs.

\subsection{Explore the Importance of the Problem}

The fact that the rate of change of professional employees in Turkish sports clubs is very short and the lack of continuity in sports success emphasizes the feeling that human factor is not given sufficient value. This study is in a position to make 
an important resource entry by examining the importance of belonging feeling.

The concept of organizational commitment, which is an indicator of harmony between employee and organization, is of great importance for all organizations (İnce and Gül 2005; Steers,1981; Çetin, 2011). The level of organizational commitment of individuals working in institutions is shown to be in parallel with the personal success of the individual and the success of the organization. It is thought that individuals with low levels of organizational commitment will not need self-renewal after a certain period of time and therefore their personal success in the institution will decrease.

As in every institution, it is thought that the organizational commitment that includes great efforts, shares, and mutual respect will be difficult to gain and easy to lose. Therefore, protecting individuals with a high sense of organizational commitment enables the development of corporate culture. We can look at people who have a sense of organizational commitment from the point of view of those who move their institutions forward. What keeps them alive and keeps their loyalty is only to see and support their actions.

Time is considered important for the development of organizational commitment. Many experiences, labor, and sharing will enable the development and consolidation of organizational commitment day by day In this sense, institutions have to support, maintain and nurture behaviors that strengthen this feeling.

Organizational change process in the independence of sports organizations and federations in Turkey is experiencing. Sports clubs have problems in terms of administrative and financial self-sufficiency (Erturan and Imamoğlu, 2011).

This study aims to determine the organizational dependence levels of sports managers in professional clubs according to various variables. This study was conducted in accordance with the quantitative research method and the data were collected via a survey.

In the research, it is thought that the success of the club will increase if the sports clubs take sufficient precautions by considering the reasons for the low level of organizational commitment determined through the variables.

In this study, the role of the following variables in the organizational commitment of sport managers will be examined.

- Does the age of the sport manager affect the level of organizational commitment to the club?

- Does the age of the sports club affect the level of organizational commitment of managers to their clubs?

- Does the sport manager's regular time in his club affect the level of organizational commitment?

- Does the duration of the sport manager's club affect the level of organizational commitment?

- Does the league where the club is located affect the organizational commitment level of the managers?

- Does it affect the level of organizational commitment that managers receive from the club where they work?

- Does the position of the sport manager (upper, middle, lower) affect the level of organizational commitment?

\subsection{Describe Relevant Scholarship}

Sports clubs can be defined as an organization that performs sports function. Sports clubs are established in order to organize social and sporting activities in line with the sports needs and demands of its members (Ekenci, 1997). The sports club is defined as organizations that work and organize certain sports branches, meet the needs of athletes such as materials and facilities, and continue their activities under the management of professional or volunteer chairmen and members (Bucher, 1987).

In this study, sports clubs with football branches were selected in Turkey, within the organizational structure of football clubs club presidents are responsible for the general assembly. Briefly, the summit of the management is the general assembly. There are club president and board members attached to the general assembly. The members of the board of directors are appointed as general captain, sub-football schools and academy, and amateur branches. The general captain is in charge of the professional department manager, technical staff manager, professional football players, service personnel (Devecioğlu, 2011).

The sports manager is the management class that provides management and administration in the sports organization where it is located, acts with the aim of using the resources of the sports organization in the most rational way and makes efforts for the success of the sports organization. A shy, non-social or introverted person cannot usually be a leader and a sports manager (Hicks 1979; quoted in: Yetim 1996).

On the other hand, according to Bucher; the sport manager is the person who organizes and develops internal and external human relationships that mobilize all elements for the realization of the goals of the sports institution, directs and manages them, leads and guides them in a certain direction and influences them. (Bucher, 1987) More specifically, it is the person who unites and organizes the efforts of the sports organization in order to achieve the most effective and efficient way to the determined goals, and monitors and controls the work and actions (Eren 2003: quoted in: Sunay 2009).

The level of duty of the sport manager is a concept related to the task authority and responsibility they take. In many clubs, it is seen that the position levels are divided into upper, middle and lower tier managers as in other enterprises. 


\subsubsection{Organizational Dependence}

Organization means the unity of institutions or individuals who have come together to realize a common purpose or action. Commitment means devotion, loyalty, and commitment. (Mercan, 2006) Grusky (1966), one of those who defined organizational commitment, described commitment as the power of an individual's commitment to the organization. (Mercan, 2006) According to this statement, the power of commitment is a concept that parallel to the level of organizational commitment.

Organizational commitment refers to a more active relationship in which individuals demonstrate a willingness to do something to help the organization succeed and achieve its goals, rather than a passive loyalty to the organization. (Ince and Gül 2005; Steers, 1981; Çetin, 2011; Kaya 2013; quoted in: Yıldız 2013) In this definition, it is stated that individuals with a high level of organizational commitment will have an active relationship for the success of their institutions.

One of the most accepted expressions of organizational commitment is the definition of Porter. According to this definition, organizational commitment is the endeavor of individuals to adopt the aims and values of the organization, to make efforts to achieve these goals and to maintain their membership in the organization (Mercan, 2006; quoted in: Çolakoğlu, 2009).

Meyer and Allen state that organizational commitment has three dimensions. Organizational commitment consists of three components: emotional, normative and continuity.

Emotional Commitment: It is related to the level of emotionality an individual feels for his organization. (Meyer and Allen, 1990) Generally, employees with strong emotional commitment prefer to stay in the organization because they feel they want to stay in their organization (Demircan, 2003; quoted in: Kaya, 2013). Individuals with strong emotional commitment see their institution as a family and feel like part of the family. Those who have a strong emotional commitment are the reason they want to stay in their institutions. (Uygur, 2004; quoted in: Kaya, 2013) In other words, the emotionality of working individuals does not allow them to leave the workplace. They put the problems of their institutions into their own problems.

Commitment to Continuity: Being aware of the obligations of leaving the organization means (Ince and Gül, 2005; quoted in: Kaya, 2013). In the commitment to continue, individuals cannot leave their institutions even if they wish. The reason is that if a person leaves the organization, it will be costly for him and will face many obligations. (Sökmen, 2000) The commitment of the individual working in continuity commitment to workplace arises from necessity rather than a sense of belonging.

Normative Commitment: In this kind of commitment, the person is connected to the institution because he/she feels responsible for the institution. (Allen and Meyer 1990; Meyer and Allen 1991) This commitment may arise when the organization offers gifts to the employer, such as scholarships, or undergoes significant costs such as education. Individuals feel obliged to their institutions. Individuals with strong normative commitment feel guilty leaving the institution, even if they have better opportunities. In this case, the employee feels the obligation to fight for his institution until he pays his debts (Allen and Meyer, 1990; Meyer and Allen, 1991).

In summary, those who have a high level of emotional commitment, because they desire to stay in the organization; those with a high level of normative commitment remain in the organization because they need to remain in the organization and those with a high level of continuation commitment need it (Bolat and Bolat, 2008; Quoting: Y1ldız, 2013).

\subsubsection{Organizational Commitment Approaches}

There are different approaches to the definition and classification of organizational commitment. These; Behavioral approaches, Attitude approach, Multiple approaches.

Behavioral Approach: It is generally evaluated from a psychological perspective. It is related to the dependence of the employees according to their experience and level of getting used to the institution. The behavioral approach is related to the problem of people being in the same institution for a long time and dealing with these problems. As time goes by, the person exhibits or acts in accordance with the institutional principles, and acts in a manner that justifies these movements and makes these behaviors permanent (Gül, 2002; quoted in: Taş, 2012). The behavioral approach is the commitment of people to the actions of the organization and not to an organization. In this approach, individuals are connected to the organization as a result of behavioral movements, not emotionally.

Attitude Approach: Attitude commitment consists of a total of three components. These; identification with the aims and values of the organization, high participation in business-related activities and loyalty and commitment to their organizations (Gül, 2002; quoted in: Taş, 2012). The attitude of an individual's work environment is called an attitude approach to the commitment of the organization to adopt the goals and values and to engage with the loyalty resulting from high participation. In the attitude approach, the individual feels passion for his organization as a whole.

Multiple Approaches: In general, in previous organizational commitment, commitment is thought to be felt throughout 
the organization. In the multiple approaches, it is accepted that there is a different level of commitment to different variables within the organization (Balay, 2000; quoted in: Taş, 2012).

\subsubsection{Factors Affecting Organizational Commitment}

There are three factors that affect organizational commitment. These are grouped under three headings: personal factors, organizational factors and gender, and non-organizational factors.

Personal Factors: we must see all individuals as a different world these differences in individuals have different results on organizational commitment. Personal factors that affect organizational commitment level are marital status, gender, length of service, age and education level. Therefore, these factors are emphasized in the study (Keleş, 2006; quoted in: Kilıç, 2008).

Organizational Commitment and Age Factor: Boon and Arumugan found that older employees had higher organizational commitment than younger employees. (Boon and Arumugam, 2006) These findings are in line with many studies in the literature. The promotion of individuals who successfully perform the necessary services, an increase in salary, will reinforce the sense of belonging of individuals. Then it will increase its organizational commitment.

According to a study conducted by Taylor Nelson Sofres among 19,840 employees in 2002, it was stated that the loyalty level of the 18-24-year-old was 49 percent and that of those 50 years and older was 57 percent (Süzer, 2003).

Organizational commitment and gender: When the literature studies are examined, no significant difference is seen in the results of the studies on the organizational commitment levels of women and men (İnce and Gül, 2005).

Organizational commitment and marital status: There are not many studies that measure organizational commitment and marital status. One of the allegations is that married employees feel organizational commitment due to their obligation to continue work resulting from their economic responsibilities. On the other hand, it is widely accepted by the researchers that there is no significant relationship between marital status and commitment (Özkaya, 2006).

Organizational commitment and education level: Generalization cannot be made because there are very different results in the studies that measure the relationship between organizational commitment and education level.

Organizational commitment and service life: It is revealed by the studies that the term of employment in institutions is one of the important variables in terms of organizational commitment (Yalçın and İplik, 2007).

Organizational Factors: When the internal factors affecting organizational commitment are examined; the form of management, internal justice, systematic structure of the organization, cooperation of the organization, organizational rewards, the scope of the work done, the possibility of employees to participate in decisions, role confusion and conflict, salary satisfaction level were determined. Organizational factors were evaluated under six headings (Balay, 2000).

Organizational commitment and quality of work

The relationship between the quality of work and organizational commitment shows parallelism. Gaining meaningfulness for an individual's work in the institution increases his commitment in the organization while recognizing the importance of his work in the external environment is stated to increase his commitment to the organization (Ince and Gül, 2005).

Organizational commitment and management style: Classical management style has been criticized throughout history for reasons such as those seen in the construction machinery, not respecting the views of those who are not valued. Since the classical style of administration does not allow the employees to realize themselves, it necessitates the transition to a democratic and pluralistic understanding of government (Zaman, 2000).

Scientific management of institutions is thought to contribute positively to the level of organizational commitment of individuals because the ability of individuals to participate in decisions and to realize themselves positively affects organizational commitment.

Organizational commitment and organizational rewards: Awards are an important tool for evaluating the superior performance of individuals working in organizations and encouraging other employees for superior performance. Barutçugil (2004) stated that those who work successfully want their work to be noticed and appreciated. It is thought that the honors of individuals by receiving awards from the institution they work in will have a positive effect on the level of organizational commitment.

Organizational commitment and wage level: In many studies, a significant difference was observed between wage level and organizational commitment. It is understood that wage level is an indicator of fairness by the employee and it is important for organizational commitment. According to these studies, it is suggested that the level of commitment to the organization will decrease gradually when the employees think that there is no justice in the wage distribution (Keleş, 2006). It is considered that individuals receive lower wages from their teammates while they have the same duties in the same institution and this will negatively affect their commitment to the organization. 
Organizational commitment and organizational trust: Organizational trust is the structure that is formed as a result of the consistent relationships established by individuals within each institution. Organizational trust contributes to the more active and successful relations within the organization and the development of communication. The fairness of the expectations of the working individuals and their meeting their expectations positively affect the levels of organizational commitment (Paine, 2007; quoted in : Demirel, 2008).

Organizational commitment and seniority expectation: It is stated that the commitment of the employee who has more seniority in the same job to the organization is higher (Dağdeviren, 2007). Meyer and Allen (1991) stated that there is a positive relationship between seniority increase and organizational commitment level within the institution.

Non-Organizational Factors Affecting Organizational Commitment: The most important of these were professionalism and new job opportunities.

Professionalism: Professionalism is a commitment to the profession and also identification with the profession. It is revealed that organizational commitment levels will be higher in organizations formed by individuals who take their profession seriously (Balay, 2000). Individuals may have expectations from their institutions after certain professionalism. In this effect, organizational commitment affects the professionalism of individuals, not institutions.

New job opportunities: It is one of the non-organizational factors that affect organizational commitment. The level of commitment to the organization will diminish as the alternatives for finding new jobs vary. It is stated that the organizational commitment level of individuals with limited job opportunities is higher for such reasons. It is accepted that individuals with a low probability of entering other jobs have a higher level of loyalty to their institution (Ince and Rose, 2005).

\subsubsection{Organizational Commitment Indicators}

There are a number of criteria used to measure the level of organizational commitment of working individuals. These are criteria that vary from person to person and do not show objectivity with the concept of space and time (Gundogan, 2009). These criteria are examined under three headings below.

Accepting and Believing the Purpose and Values of the Organization: Within organizations, people can have goals and act to achieve their goals (Öztürk, 2013). The goals of organizations are jointly formed and developed by individuals involved in the organization. It is unthinkable that an employee who cannot accept the goals and values of an organization shows commitment to that organization (Bülbül, 2007). In this context, the importance of individuals for organizational purposes is understood. Workers have thoughts such as being able to realize themselves within the framework of their expectations from life and they want to get support from these organizations in these issues. The fact that organizations support these issues increases the level of organizational commitment. The expectations of individuals from their organizations and their level of fulfillment are important criteria in terms of organizational commitment (Dolu, 2011).

Making Sacrifices for the Organization: All individuals working in the institution have obligations that they fulfill for their institutions. An individual is defined as an indicator of organizational commitment by deducting from his / her private life while observing the aims of the institution. It is interpreted that individuals who work for organization success and do not hesitate to make sacrifices for their organizations adapt their organization and have a sense of belonging (Gündoğan, 2009).

Identification with Organizational Identity: Identification with Organizational Identity: Belonging to a group is considered as an element that increases organizational commitment because it contributes to individuals' self-recognition and self-realization. The higher the corporate image and credibility as prestige, the more employees identify with their institutions (Dolu, 2011). Identification is due to the dynamic energies, self-confidence, and visions of corporate executives (Bülbül, 2007).

\subsubsection{Results of Organizational Commitment}

Organizational commitment is generally accepted as an indication of unwillingness to leave the organization, willingness to do more work for the organization and regular job indicator. In this context, organizational commitment is divided into three levels and examined under the following headings (Kiray, 2011).

Low level of organizational commitment: The positive outcomes of the low level of organizational commitment for the employee are that the performance is not sufficient. The negative results for the institutions are that the quality of the work is below expectations, low belonging to the institution, the desire not to continue in the organization, exhibiting limited over-role behavior, negative behaviors towards the organization, failure, and harm to the institution (Özcan, 2008).

Moderate Organizational Commitment: Moderate organizational commitment is a strong but not identifiable experience of the working experience and incomplete organizational commitment. Moderate level of organizational commitment can be defined as balancing of individuals' own interests and corporate interests. Employees at this level tend to accept some values, not all values of the organization in which they work. Employees at this level, while maintaining ownership of the organization, also take into account their personal values (Kılınç, 2013). 
High Organizational Commitment: High level of organizational commitment is seen as a positive concept for both individuals and institutions. The characteristics of this type of commitment include factors such as people wanting to stay in their institutions for a long time and decreasing the number of quitting their jobs. Employees sincerely and sincerely immerse themselves in the membership of the organization. For these reasons, they do not prefer to leave their institutions easily. Individuals who exhibit this level of commitment to their organizations are both affected by their organizations quickly and tend to influence their own organizations (Imamoğlu, 2011).

Workers at this level become dependent on the goals of the organization that is in agreement with their own ideas and achieve job satisfaction in many respects. These people will show their commitment to their organizations by providing superior performance and successful service because they do not have any expectations and quests (Başyiğit, 2006).

\section{Method}

\subsection{Population and Sample}

The study population consisted of manage sports clubs in Turkey. The sample includes some sports club managers from the super league, 1st league, 2nd league 3rd league BAL league and Amateur league teams.

\subsection{Method}

The aim of this study is to determine the levels of organizational dependence of sports managers in professional clubs according to various variables. This study was conducted in accordance with the quantitative research method. A questionnaire was applied to the participants. In the preparation of the personal information, the help of the academicians who are experts in psycho-social fields in sports was taken during the preparation of the variables.

\subsection{Working Group}

The working group of the study consists of a total of 74 people including eleven from Super League clubs, eleven from first league clubs, nine from second league clubs, nine from third league clubs, thirty-four from Amateur league clubs.

\subsection{Data Collection Tools}

In this study, Organizational Commitment Scale, which was developed by Meyer-Allen (1984) and tested in numerous studies, was used to determine the organizational commitment levels of sports club managers. The sub-dimensions of the scale are divided into three as emotional commitment, continuity commitment, and normative commitment. The scale was structured according to a 5-point Likert scale. The overall score of the scale gives the organizational commitment score.

\subsubsection{Organizational Commitment Scale}

The scale was adapted as "strongly disagree $=1$ ", disagree $=2$ ", undecided $=3$ ", "agree $=4$ ", "strongly agree $=5$ ". The organizational commitment scale consists of three dimensions. These consist of continuation commitment, emotional commitment, and normative commitment. The first six questions of the scale included emotional commitment questions $(1,2,3,4,5,6)$, continuity commitment questions from the sixth to eighteenth questions $(7,8,9,10,11,12)$, from the twelfth to the eighteenth question. as normative commitment questions $(13,14,15,16,17,18)$. The 13th question of the scale is scored in reverse (Al 2007; Oruç, 2013). Meyer and Allen (1991) found 0.82, 0.74 and 0.83 alpha values for the emotional, continuation and normative commitment dimensions of organizational commitment, respectively (Al, 2007; Oruç, 2013; Mamedov, 2013). Many times validity and reliability study of the scale of organizational commitment made in Turkey and was determined not to differ from the original scale.

\subsubsection{Data Analysis}

In this study, the level of organizational commitment of sports club managers according to various variables was examined. In the process of data interpretation, non-parametric tests such as Mann Whitney U and Kruskal Wallis tests were used after SPSS 21 Packet program normality test.

\section{Results and Conclusion}

A total of 74 sports managers participated in the study in order to determine organizational commitment levels according to various variables and to determine whether organizational commitment levels differ according to personal information. The distribution of sports managers participating in the research according to the clubs is as follows. 11 managers from the super league, 11 managers from the first league, 9 managers from the second league, 9 managers from the third league, 15 managers from Regional Amateur League (RAL) and 19 managers from national amateur leagues. The following conclusions were reached in this research:

The first variable of the study did not find a statistically significant difference between the mean age groups according to age findings. 
Table 3.1. Age variable and organizational dependence

\begin{tabular}{l|l|l}
\hline Manager Age & Commitment Level Score & Ranking \\
\hline $19-24$ & 53.50 & 1 \\
\hline $25-29$ & 28.55 & 6 \\
\hline $30-39$ & 31.50 & 5 \\
\hline $40-49$ & 44.09 & 3 \\
\hline $50-59$ & 33,23 & 4 \\
\hline 60 and Above & 48.88 & 2 \\
\hline
\end{tabular}

When the commitment level score and rankings were examined, it was seen that the age variable did not affect the organizational commitment level.

According to these results, it is seen that the age variable does not affect organizational commitment level significantly. When the literature is examined, we find that parallel to the results of this study, there are also contradictory results.

Angle and Perry (1981), in the study of individuals, found that the level of commitment increases with the level of age increases. In a more explicit way, they stated that the elderly individuals' finding alternative jobs and getting additional training to improve themselves decreased as a result of this, the loyalty of the employees to the organization they work for increased.

Allen and Meyer (1993) investigated the relationship between organizational commitment and age by considering all three dimensions of organizational commitment. According to this study, the level of emotional commitment increases as the individual's age increases, while the age of the employee has no effect on commitment (Keles, 2006; quoted in: Taş, 2012).

In this study, the reason why the age variable does not show a parallel relationship with the organizational commitment is shaped by the love, volunteerism and the position of the club managers rather than the age variable. The organizational commitment of individuals, even if they are young or older, is not related to age but to the expression of love for their club. For these reasons, the age variable remains in the background compared to other variables.

The second variable of the study was determined that club age did not affect organizational commitment and no statistically significant difference was observed between the groups. Club age and level of commitment level score were taken to the table below.

Table 3.2. Club Age and Commitment Level Score

\begin{tabular}{l|l|l}
\hline Club Age & Commitment Level Score & Ranking \\
\hline $0-20$ & 34,83 & 5 \\
\hline $21-40$ & 34,83 & 5 \\
\hline $41-60$ & 35.00 & 4 \\
\hline $61-80$ & 35,32 & 3 \\
\hline $101-100$ & 55,13 & 1 \\
\hline
\end{tabular}

When the commitment level score and rankings were examined, it was seen that the club age variable did not affect the organizational commitment level.

As a result of the Mann Whitney $\mathrm{U}$ test, the 3rd variable of the research was conducted according to whether you regularly spend time in your club. A statistically significant difference was found between the levels of organizational commitment scores of the managers who spent regular time in the club and those who did not spend regular time.

When the scores were evaluated, the organizational commitment level score of those who answered yes to the question of having regular time in their club was determined as (44.53), and the organizational commitment level score of those who answered no were determined as (20.89).

According to these results, the scores of the managers who spend time in the club were found to be much higher than the ones who did not. At the end of these evaluations, it can be concluded that those who have an organizational commitment to the sports club spend more time in their clubs and that regular time affects organizational commitment positively to the club.

As a result of the Kruskal Wallis test, the fourth variable of the study, taking into account the time spent in the club, there was no statistically significant difference between the averages of the groups. 
Table 3.3. Term in the Club and Commitment Level Score

\begin{tabular}{l|l|l}
\hline The term in the club (year) & Organizational Commitment Score & Ranks \\
\hline $1-3$ & 32.84 & 5 \\
\hline $4-5$ & 35,88 & 4 \\
\hline $6-7$ & 45,82 & 1 \\
\hline $8-9$ & 45.80 & 2 \\
\hline 10 and above & 43.58 & 3 \\
\hline According to these & & \\
\hline
\end{tabular}

According to these scores, it was understood that the duty duration variable did not significantly affect the organizational commitment level.

It was determined that the duty period variable in the club did not significantly affect the level of organizational commitment. In the literature studies, it is seen that different results were obtained. As the time spent in the organization's increases, the investments of the employees increase in their organizations and they do not want to leave their organizations in order not to be deprived of their investments. Thus, there is a significant relationship between organizational commitment and seniority. It is interpreted that there are positive results between organizational commitment and seniority such as seniority, a status achieved, monthly salary, respect, and reputation obtained after long term duties in the organization (Özkaya,2006; quoted in: Taş, 2012).

The fifth variable of the study was added to the study to determine the effect of the club's league on the level of organizational commitment on its managers.

As a result of the Kruskal Wallis test for this variable, a statistically significant difference was found between the means of the groups.

Table 3.4. League Scale and Organizational Commitment Score

\begin{tabular}{l|l|l}
\hline \multicolumn{1}{c|}{ League Scale } & Organizational Commitment Score & Ranks \\
\hline Super League & 59.05 & 1 \\
\hline 1st League & 30.09 & 5 \\
\hline 2nd League & 38.72 & 3 \\
\hline 3rd League & 32.06 & 4 \\
\hline Regional Amateur League & 43.47 & 2 \\
\hline National Amateur League & 26.61 & 6 \\
\hline
\end{tabular}

It was seen that the league variable where the club is located affects the level of organizational commitment.

The reason why amateur club managers have the lowest organizational commitment score is the example of their voluntary duties in the club. According to the results, the reason for the low level of loyalty can be attributed to reasons such as being obliged to their duties rather than their love for clubs. Since the distributions are not in a hierarchical order, organizational commitment and league level do not show parallelism.

The sixth variable of the research was added to evaluate the effect of the wages received by the managers for their duties in the club on organizational commitment.

As a result of the Mann Whitney U test, no statistically significant difference was observed between the organizational commitment scores of the managers who earn wages from the club and the volunteers who do not earn wages.

When the scores are evaluated, the organizational commitment level score of the wage earners for the tasks in the club (37.45), the organizational commitment level score of those who did not receive remuneration for the tasks I was assigned to (37.54). It can be said that the level of organizational commitment of the employees is high on the basis of volunteering in clubs.

Therefore, attendance commitment scores are estimated to be higher. Örs et al. (2003) stated that the level of organizational commitment of doctors was higher than that of nurses. The reason for the difference in loyalty levels is explained by the fact that the share of revolving funds earned by the specialist doctors from the hospitals they work in is higher than the nurses (Stone, 2012).

The seventh variable of the research is aimed to measure the effect of status of sport club managers on organizational commitment level. As a result of the Kruskal Wallis test, a statistically significant difference was observed between the 
scores of organizational commitment levels of the groups. According to the scoring, it was determined that the organizational commitment score (47.44) of the managers who defined the top level in their clubs, the score of the managers who defined the middle level (30.64) and the score of the managers who defined the lower level (15.54).

It was seen that the level in which the managers worked in the clubs affected the level of organizational commitment. According to this result, the level of organizational commitment increases from low-level tasks to high-level tasks. In summary, it is estimated that the level of self-actualization of the level managers is higher, which has positive effects on the level of commitment to the organization. Managers' right to voice in the club and their levels of organizational commitment are parallel. As a result, when all variables were taken into consideration, it was observed that the results were not similar to the studies in the literature.

As a result, it is understood that the age of the employees in the clubs, the term of duty, the wages they receive and the age of the club do not significantly affect the level of organizational commitment. Besides, It has been seen that the league, where the club is located, the level of duty of the managers, and having a regular time in the club affect the level of organizational commitment.

\section{Discussion}

Table 4.1. Normality Test According to Age Variable

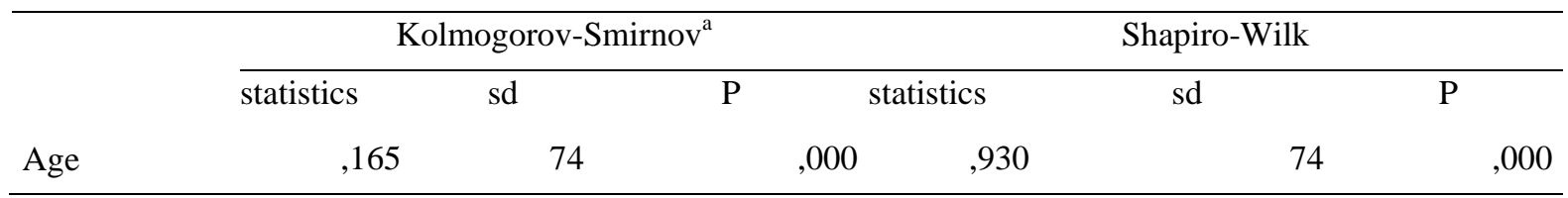

As a result of the normality test according to the age variable, it was determined that the groups were not distributed normally $(\mathrm{P}<0.05)$. According to this result, the Kruskal Wallis test, which is a non-parametric test, was considered appropriate.

HO: In this study, there is a significant difference between organizational commitment and age.

H1: There is no significant difference between organizational commitment and the age variable in this study

Table 4.2. Kruskal Wallis Test According to Age Variable

\begin{tabular}{llccc}
\hline & Age & \multicolumn{2}{c}{ Average rating } & P \\
\hline \multirow{4}{*}{ Average } & $\ldots$ 25 -24 Age group & 1 & 53,50 &, 121 \\
& 25-29 Age group & 11 & 28,55 & \\
& 30-39 Age group & 16 & 31,50 & \\
& 40-49 Age group & 23 & 44,09 & \\
& 50-59 Age group & 15 & 33,23 & \\
& 60-... Age group & 8 & 48,88 \\
\end{tabular}

When Kruskal Wallis test results were examined, there was no statistically significant difference between the groups' means $(\mathrm{P}>0.05)$. The age variable did not affect the level of organizational commitment. H0 hypothesis was rejected.

Table 4.3. Normality Test According to Club Age Variable

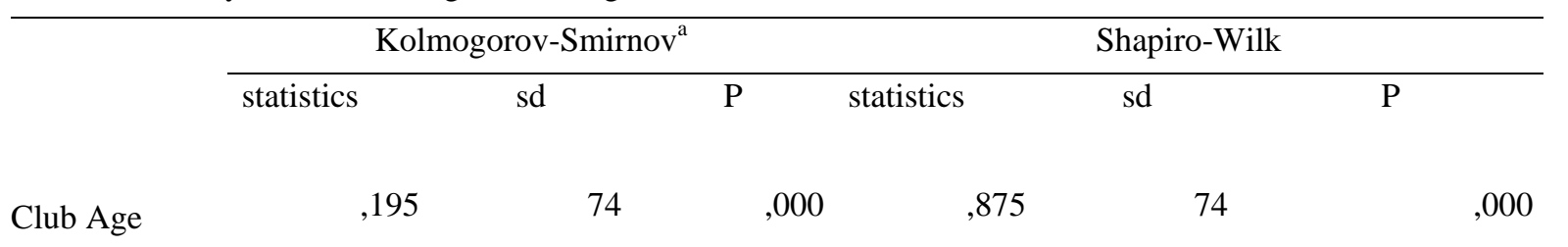

As a result of the normality test according to the club age variable, it was determined that the groups were not distributed normally $(\mathrm{P}<0.05)$. According to this result, the Kruskal Wallis test, which is a non-parametric test, was considered appropriate.

H0: In this study, there is a significant difference between organizational commitment and club age variable.

H1: In this study, there is no significant difference between organizational commitment and club age variable. 
Table 4.4. Kruskal Wallis Test According to Club Age Variable

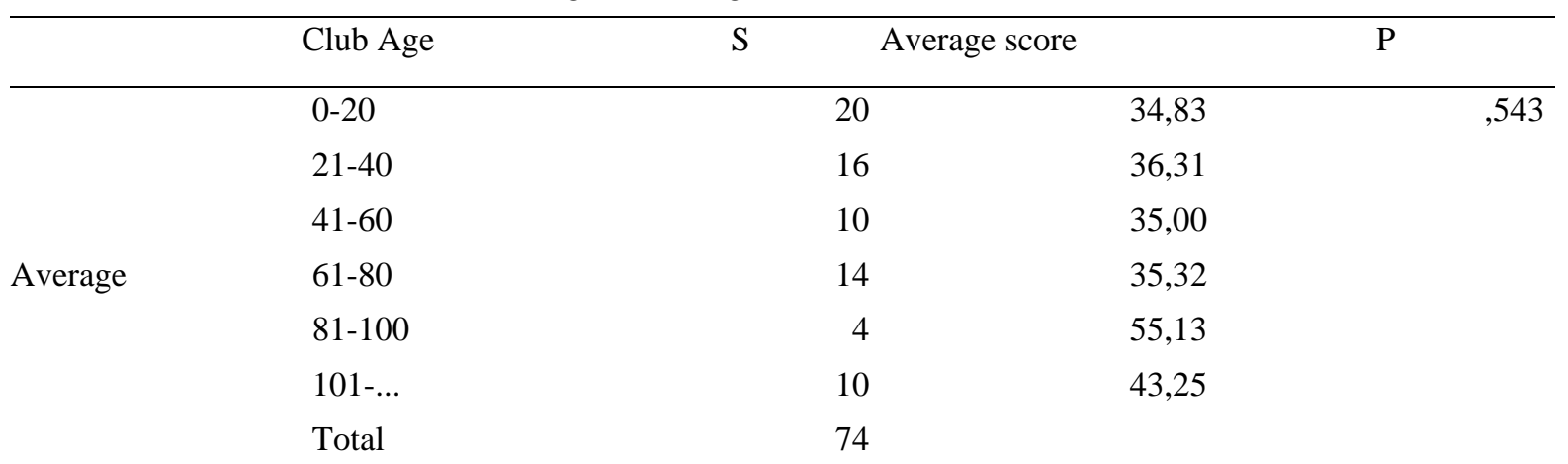

When Kruskal Wallis test results were examined, there was no statistically significant difference between the groups' means $(\mathrm{P}>0.05)$. It was observed that the club age variable did not affect the level of organizational commitment. H0 hypothesis was rejected.

Table 4.5. Normality Test According to Regular Time Pass Variable

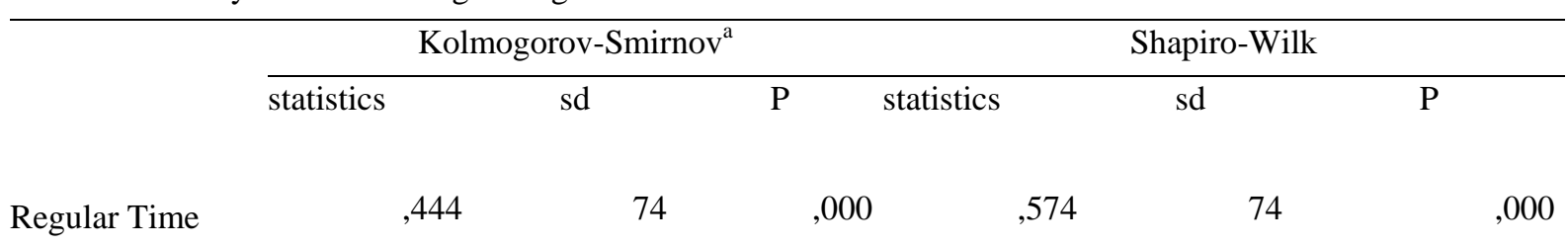

As a result of the normality test performed according to the regular time variable, the groups were not distributed normally $(\mathrm{P}<0.05)$. According to this result, non-parametric Mann Whitney u test was considered appropriate.

H0: In this study, there is a significant difference between organizational commitment and regular time spent in the club. H1: In this study, there is no significant difference between organizational commitment and regular spending time in the club.

Table 4.6. Mann Whitney U Test According to Regular Time Shift Variable in Club

\begin{tabular}{llrrrr}
\hline & Regular time & S & \multicolumn{2}{c}{ Average } & \multicolumn{2}{c}{ Total of rows } & P \\
\hline \multirow{3}{*}{ Average } & Yes & 52 & 44,53 & 2315,50 & .000 \\
& No & 22 & 20,89 & 459,50 & \\
& Total & 74 & & &
\end{tabular}

As a result of the Mann Whitney $U$ test, there was a statistically significant difference between the organizational commitment scores of the managers who spent regular time in the club and those who did not spend regular time $(\mathrm{P}$ $<0.05)$.

According to the scores, the organizational commitment level score of the participants who answered yes to the question of having regular time in the club was determined as (44.53), and the organizational commitment level score of those who answered no were determined as (20.89). H1 hypothesis was rejected.

Table 4.7. Normality Test According to Duty Time Variable

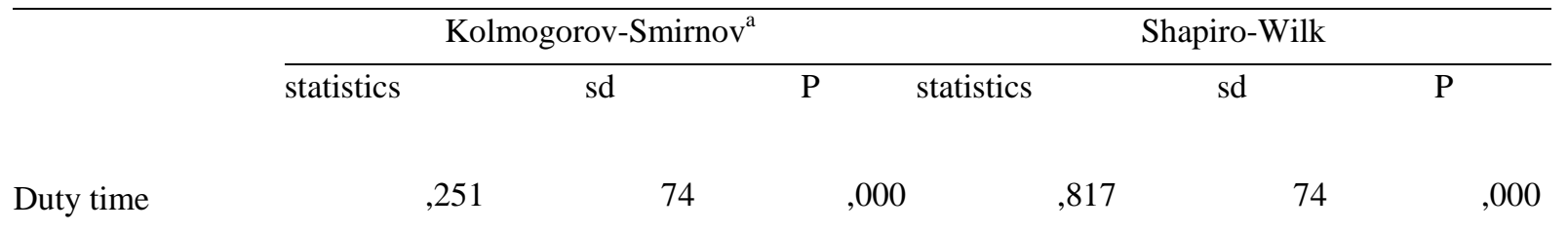

In the normality test according to the duration of duty variable, it was determined that the groups were not distributed normally $(\mathrm{P}<0.05)$. According to this result, the Kruskal Wallis test, which is a non-parametric test, was considered appropriate.

H0: In this study, there is a significant difference between organizational commitment and duty variable.

H1: In this study, there is no significant difference between organizational commitment and tenure variable. 
Table 4.8. Kruskal Wallis Test According to Duty Period Variable

\begin{tabular}{|c|c|c|c|c|}
\hline & Duty time & $\mathrm{S}$ & Average score & $\mathrm{P}$ \\
\hline \multirow{6}{*}{ Average } & 1-3 year & 28 & 32,84 & \multirow[t]{6}{*}{, 363} \\
\hline & 4-5 year & 24 & 35,88 & \\
\hline & 6-7 year & 11 & 45,82 & \\
\hline & $8-9$ year & 5 & 45,80 & \\
\hline & 10- year & 6 & 43,58 & \\
\hline & Total & 74 & & \\
\hline
\end{tabular}

When Kruskal Wallis test results were examined, there was no statistically significant difference between the groups' means $(\mathrm{P}>0.05)$. It was seen that the term of duty taken at the club did not affect the level of organizational commitment.

H0 hypothesis was rejected.

\begin{tabular}{cccc}
\hline League & S & Average rating & P \\
\hline Süper League & 11 & 59,05 &, 002 \\
$1^{\text {st }}$ league & 11 & 30,09 & \\
$2^{\text {nd }}$ league & 9 & 38,72 & \\
$3^{\text {rd }}$ league & 9 & 32,06 &
\end{tabular}

RAL

Average

$15 \quad 43,47$

Amateur $\quad 19 \quad 26,61$

Total 74

Table 4.9. Normality Test According to the League Variable

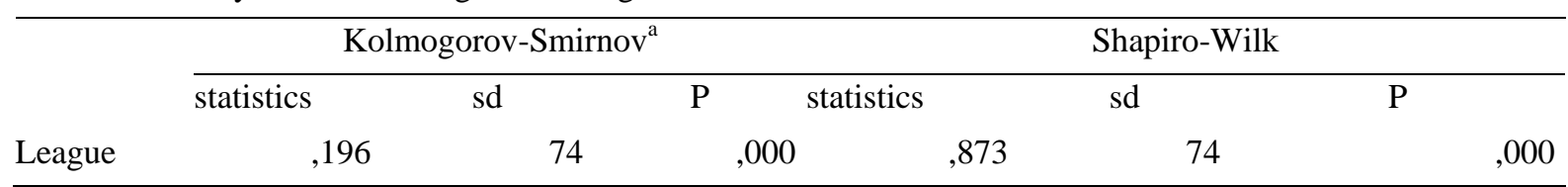

As a result of the normality test according to the league variable where the clubs are located, it was determined that the groups were not distributed normally $(\mathrm{P}<0.05)$.

According to this result, the Kruskal Wallis test, which is a non-parametric test, was considered appropriate.

H0: In this study, there is a significant difference between organizational commitment and the league variable where the club is located.

H1: In this study, there is no significant difference between organizational commitment and the league variable where the club is located.

Table 4.10. Kruskal Wallis Test According to League Variable

When Kruskal Wallis test results were examined, there was a statistically significant difference between the mean values of the groups $(\mathrm{P}<0.05)$.

It was seen that the league variable where the club is located affects the level of organizational commitment.

H1 hypothesis was rejected. 
Table 4.11. Tamhane's T2 Test According to League Variable

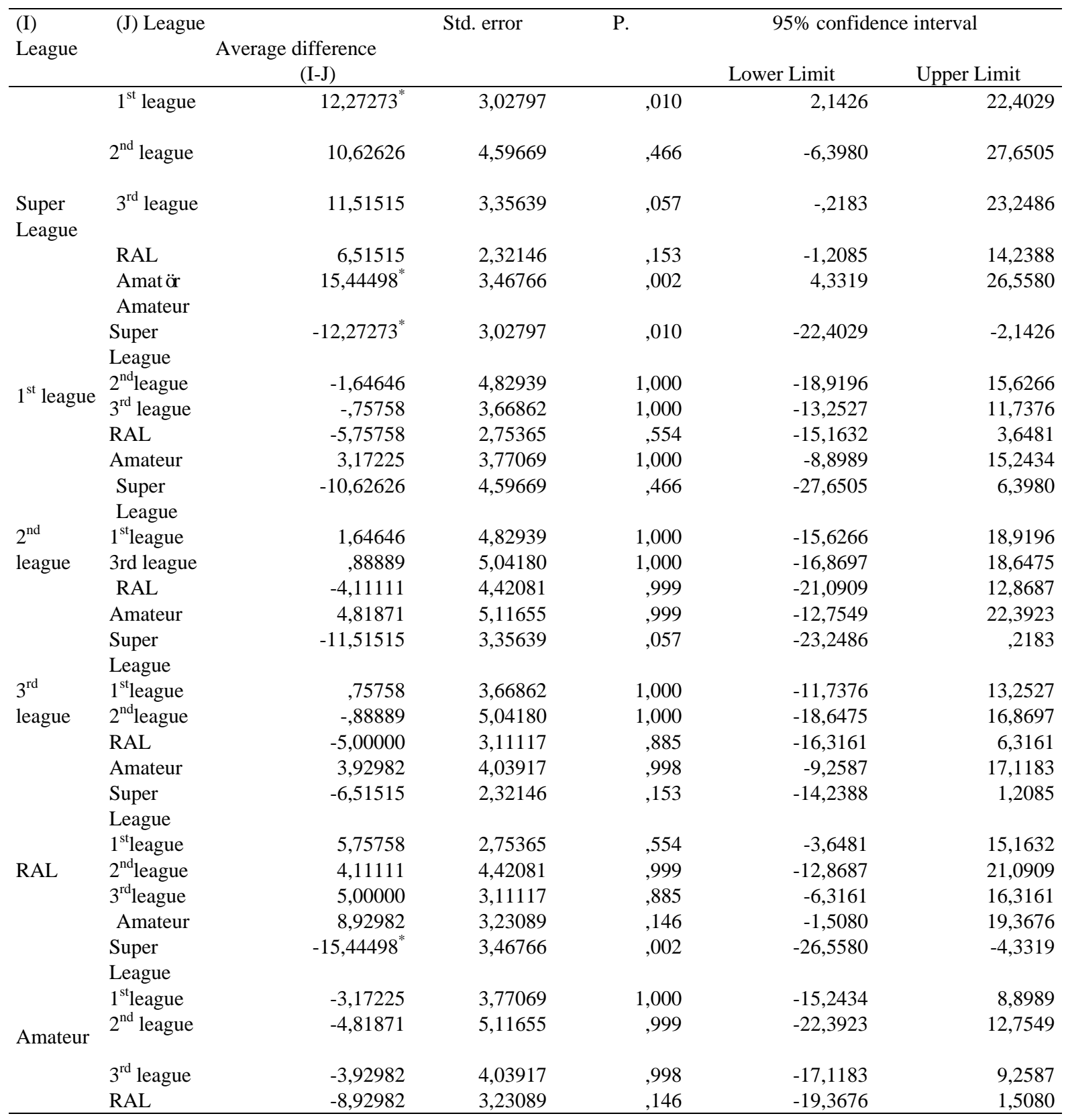

According to the Tamhane's T2 test, there were a significant difference between Super League, 1st league and Amateur league team managers $(\mathrm{P}<0,05)$. No significant difference was found between the 2 nd league, 3rd league and Regional Amateur league groups with the other groups $(\mathrm{P}>0.05)$.

Table 4.12. Normality Test According to Wage Variable

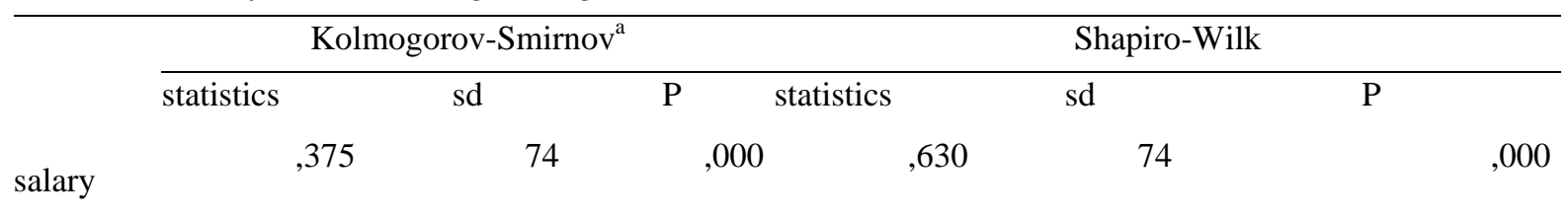

As a result of the normality test according to the wage variable, it was determined that the groups were not distributed normally ( $\mathrm{P}<0.05$ ). Following this result, non-parametric test, Mann Whitney $\mathrm{U}$ test, was considered appropriate.

H0: In this study, there is a significant difference between organizational commitment and the wage variable.

H1: There is no significant difference between organizational commitment and the wage variable in this study. 
Table 4.13. Mann Whitney U Test According to Fee Variable

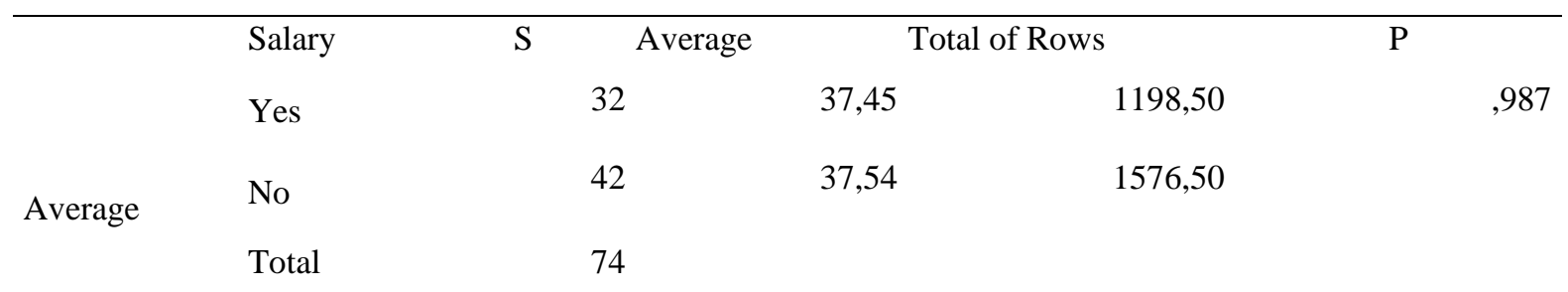

According to the results of Mann Whitney U test, no statistically significant difference was observed between the organizational commitment scores of the managers who spent regular time in the club and the managers who did not spend regular time $(\mathrm{P}>0.05)$. When the ratings are; The level of organizational commitment of the respondents who answered yes to the question of getting paid for the tasks in the club was determined as the level of organizational commitment (37.45), while the organizational commitment level score of those who gave no response was determined as (37.54).

H0 hypothesis was rejected.

Table 4.14. Normality Test According to Position Variable

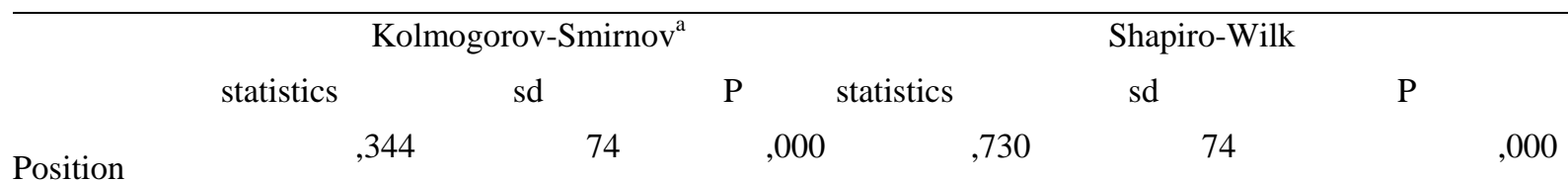

As a result of the normality test according to the position variable, it was determined that the groups were not distributed normally ( $\mathrm{P}<0.05)$. After this result, the non-parametric test Kruskal Wallis test was considered appropriate.

H0: In this study, there is a significant difference between organizational commitment and task position variable. H1: In this study, there is no significant difference between organizational commitment and task position variable.

Table 4.15. Kruskal Wallis Test According to Position Variable

\begin{tabular}{|c|c|c|c|c|}
\hline & Position & $\mathrm{S}$ & Average & $\mathrm{P}$ \\
\hline & & 41 & 47,44 & ,000 \\
\hline & top-level & & & \\
\hline \multirow[t]{3}{*}{ Average } & intermediate level & 21 & 30,64 & \\
\hline & lower level & 12 & 15,54 & \\
\hline & Total & 74 & & \\
\hline
\end{tabular}

When Kruskal Wallis test results were examined, there was a statistically significant difference between the mean values of the groups $(\mathrm{P}<0.05)$. It was seen that the level at which the managers worked in the clubs affected the level of organizational commitment. H1 hypothesis was rejected.

Table 4.16. Tamhane's T2 Test According to Position Variable

\begin{tabular}{|c|c|c|c|c|c|c|c|}
\hline \multirow[t]{3}{*}{ (I) } & \multirow{3}{*}{$\begin{array}{l}\text { Positio } \\
n\end{array}$} & \multirow[t]{3}{*}{ (J) Position } & \multirow{2}{*}{$\begin{array}{l}\text { Average difference } \\
(\mathrm{I}-\mathrm{J})\end{array}$} & \multirow{3}{*}{$\begin{array}{l}\text { Std. error } \\
2,31464\end{array}$} & \multirow[t]{2}{*}{ P. } & \multicolumn{2}{|c|}{$95 \%$ confidence interval } \\
\hline & & & & & & lower limit & upper limit \\
\hline & & & $7,74564^{*}$ & & ,006 & 1,9411 & 13,5501 \\
\hline & & intermediate & & & & & \\
\hline \multirow{4}{*}{\multicolumn{2}{|c|}{ top level }} & & $16,90041^{*}$ & 3,24716 &, 000 & 8,1535 & 25,6474 \\
\hline & & lower level & & & & & \\
\hline & & & $-7,74564^{*}$ & 2,31464 &, 006 & $-13,5501$ & $-1,9411$ \\
\hline & & top level & & & & & \\
\hline \multirow{3}{*}{\multicolumn{2}{|c|}{ intermediate }} & & 9,15476 & 3,61103 & 057 &,- 2330 & 18,5425 \\
\hline & & lower level & & & & & \\
\hline & & & $-16,90041^{*}$ & 3,24716 &, 000 & $-25,6474$ & $-8,1535$ \\
\hline \multirow{2}{*}{\multicolumn{2}{|c|}{ lower level }} & & $-9,15476$ & 3,61103 & 057 & $-18,5425$ &, 2330 \\
\hline & & lower level & & & & & \\
\hline
\end{tabular}

When the Tamhane's T2 test table of the managers who defined a high level of duty was examined, it was found that there was a significant difference between the groups that defined the middle level and lower level of duty (P<0.05). According to these results, it was determined that the organizational commitment scores of the managers who defined 
that they were taking high-level tasks $(7,74564)$ were more than the managers who defined that they were taking middle level with the difference and the organizational commitment scores of the managers who defined that they were taking high-level tasks $(16,90041)$ It was found to be more than the managers.

\section{References}

Ahmad, K. Z., \& Bakar, R. A. (2003). The Association Between Training and Organizational Commitment Among White-Collar Workers in Malaysia. International Journal of Training and Development, 7(3), 166-185. https://doi.org/10.1111/1468-2419.00179

Al, A. (2007). Investigation of Managerial Competence Levels of Organizational Commitment Levels of English Language Instructors of Managers of Foreign Languages Units in Universities. Master Thesis, Kocaeli University Institute of Social Sciences, Kocaeli.

Angle, H. L., \& Perry, J. L. (1981). An Empirical Assessment of Organizational Commitment and Oganizational Effectivenes. Administrative Science Quarterly, (26), 1-14. https://doi.org/10.2307/2392596

Aven, F., Parker, B., \& Mcevoy, G. M. (1993). A Meta-Analysis. Journal of Business Research. (26), 63-73. https://doi.org/10.1016/0148-2963(93)90043-O

Balay, R. (2000). Organizational Commitment to Managers and Teachers. Ankara: Nobel Publication Distribution.

Barutçugil, İ. (2004). Strategic Human Resource Management. İstanbul: Kariyer Yayıncılık Contact Education Services Ltd.Şti.

Basyigit, A. (2006). The Effect of Organizational Communication on Organizational Commitment. Master Thesis, Dumlupınar University, Institute of Social Sciences, Kütahya.

Bolat, O. Ş., \& Bolat, T. (2008). The Relationship Between Organizational Commitment and Organizational Citizenship Behavior in Hotels. Balikesir University Journal of the Institute of Social Sciences. (19), 75-94.

Boon, O. K., \& Arumugam, V. (2006). The Influence of Corporate Culture on Organizational Commitment: Case Study of Semiconductor Organizations in Malaysia. Sunway Academic Journal. (3), 110.

Bruning, N. A., \& Snyder, R. A. (1983). Sex and Position as Predictors of Organizational Commitment. Academy of Management Journal, (26), 485-491. https://doi.org/10.2307/256259

Bucher, C. A. (1987). Management of physical education and athletic programs. Toronto: 9th Edition, Times Mirror / Mosby College Publishing.

Bulbul, M. (2007). Organizational Commitment and Research for Public Institutions. Master Thesis, Kahramanmaras Sutcu Imam University Institute of Social Sciences.

Çekmecelgoğlu, H. (2006). Evaluation of the Effects of Job Satisfaction and Organizational Commitment Attitudes on Job Intention and Productivity A Research.Journal of Work, Power Industrial Relations and Human Resources. (2), 153-168.

Cetin, F., Basim, H., Basim, N., \& Aydogan, O. (2011). The Relationship Between Organizational Commitment and Burnout A Research on Teachers, Selçuk University Journal of Social Sciences Institute, 61-70.

Çetin, M. Ö. (2004). Organizational Culture and Organizational Commitment. Ankara: Nobel Publication Distribution.

Chughtai, A. A., \& Zafar, S. (2006). Antecedents and Consequences of Organizational Commitment Among Pakistani University Teachers. Applied H.R.M. Research. (11), 39-64.

Chusmir, L. H. (1982). Job Commitment and Organizational Women. Academy of Management Review. (7), 595-602. https://doi.org/10.5465/amr.1982.4285252

Cimen, Z., \& Ekenci, G. (2003) Level of the realization of the purpose of the establishment of Sports Clubs: Public, Local and Other Sports Clubs Comparison. Journal of Physical Education and Sport Sciences. 8 (4), 77-91.

Çolakoğlu, Ü., Ayyıldız, T., \& Cengiz, S. (2009). Perception Differences in Organizational Commitment Dimensions According to Demographic Characteristics of Employees: The Case of Five Star Accommodation Businesses in Kuşadas1. Journal of Tourism Research. (1), 77-89.

Cromie, S. (1981). Women as Managers in Northern Ireland. Journal of Occupational Psychology. (54), 87-91. https://doi.org/10.1111/j.2044-8325.1981.tb00047.x

Dağdeviren, E. G. (2007). Uygulama An Application on Job Satisfaction and Organizational Commitment Insurance Companies.Master Thesis, Atılım University, Institute of Social Sciences, Ankara.

Demircan, N. (2003). The Effect of Organizational Trust on Organizational Commitment as an Intermediate Variable: An 
Application in Education Sector. Unpublished PhD Thesis, Gebze Institute of Advanced Technology Institute of Social Sciences. Gebze.

Demirel, Y. (2008). The Effect of Organizational Trust on Organizational Commitment: A Research for Textile Sector Employees Management and Economics. (15), 179-194.

Desert, G., \& Gul, H. (2005). The Effects of Personal Characteristics on Organizational Commitment and an Application in Public Universities. Journal of Economics and Administrative Sciences. (19), 293-306.

Devecioglu, S., Coban, B., \& Karakaya, Y. E. (2011). Evaluation of Management Models of Sports Clubs. Dumlupinar University Journal of Social Sciences. (31), 51-68.

Dolu, B. (2011). A Research on Organizational Commitment Levels of Employees in the Banking Sector. Non-Thesis Master Project. Süleyman Demirel University, Institute of Social Sciences, Isparta.

Ekenci, G. (1997). Effects of Human and Environmental Relations on Sports Club Management. Gazi Journal of Physical Education and Sport Sciences. (4), 35-43.

Ellemers, N., Van Den Heuvel, H., Gilder, D., Maass, A. \& Bonvını, A. (2004). The Underrepresentation of Women in Science: Differential Commitment or The Queen Bee Syndrome. British Journal of Social Psychology. (43), 315-338. https://doi.org/10.1348/0144666042037999

Eren, E. (2003). Management and Organization (contemporary cultural approaches). Istanbul: Beta Press Release.

Erturan Counsel, E., \& İmamoğlu, A. F. (2011). Comparative Analysis of Germany and Sports Club A New Approach to the Construction and Operation of the Sports Club in -TURKEY in Turkey. Journal of Sport Sciences Hacettepe J. of Sport Sciences. (22), 54-68.

Fry, L. W., \& Greenfield, S. (1980). An Examination of Attitudinal Differences Between Policewomen and Policemen. Journal of Applied Psychology. (65), 123-126. https://doi.org/10.1037/0021-9010.65.1.123

Glisson, C., \& Durick, M. (1988). Predictors of job satisfaction and organizational commitment in human service organizations. Administrative Quarterly. 61-81. https://doi.org/10.2307/2392855

Graddick, M. M., \& Farr, J. L. (1983). Professionals in Scientific Disciplines: Sex-Related Differences in Working Life Commitments.Journal of Applied Psychology. (68), 641-645. https://doi.org/10.1037/0021-9010.68.4.641

Grusky, O. (1996). Career Mobility and Organizational Commitment. Administrative Science Quarterly. (10), 488-503. https://doi.org/10.2307/2391572

Gül, H. (2002). Comparison and Evaluation of Organizational Commitment Approaches. Ege University Journal of Academic View. (1), 37-55.

Gundogan, T. (2009). Organizational commitment: Application of Central Bank of the Republic of Turkey. Expertise Proficiency Thesis, General Directorate of Human Resources Central Bank of the Republic of Turkey, Ankara.

Hail, B. (2011). A Research on Organizational Commitment Levels of Employees in the Banking Sector. Non-Thesis Master Project. Süleyman Demirel University, Institute of Social Sciences, Isparta.

Hicks, H. G. (1979). Örgütlerin Yönetimi: Sistemler ve Beşeri Kaynaklar Açısından. İstanbul.

Hrebınıak, L. G., \& Alutto, J. A. (1972). Personal and Role-Related Factors in the Development of Organizational Commitment. Administrative Science Quarterly. (72), 555-572. https://doi.org/10.2307/2393833

Imamoglu, G. (2011). The Relationship Between Organizational Commitment Levels and Organizational Justice Perceptions of Primary School Teachers. Master Thesis, Gazi University, Institute of Educational Sciences, Ankara.

Ince, M., \& Gul, H. (2005). A New Paradigm in Management: Loyalty. Çizgi Bookstore Publications.

Kathleen, D., \& Fox M. L. (2008). Leadership Style and Organizational Commitment: Mediating Effect of Role Stress. Journal of Managerial. 109-130.

Kaya, Y. (2013). The Relationship Between Organizational Commitment and Organizational Cynicism and Organizational Opposition. International Periodical For Languages, Literature and History of Turkish or Turkic Volume. 853-879.

Keles, H. N. (2006). A Research on the Effect of Job Satisfaction on Organizational Commitment in Pharmaceutical Production and Distribution Companies. PhD Thesis, Selcuk University, Institute of Social Sciences, Konya.

Kennedy, J. R., \& Anderson, R. D. (2005). Subordinate-Manager Ender Combination and Perceived Leadership Style Influence on Motions, self-esteem and Organizational Commitment. Journal of Business Research. (58), 115-125. https://doi.org/10.1016/S0148-2963(03)00112-7 
Kilic, G. (2008). The Relationship Between Career Management and Organizational Commitment: A Research in Five Star Hotel Establishments. PhD Thesis, Gazi University, Institute of Educational Sciences.

Kilinc, D. T. (2013). The Relationship Between Classroom Teachers 'Perceptions of Transformational and Interactiveist Leadership Styles and Their Organizational Commitment and School Principals' Perceptions of Organizational Commitment of Classroom Teachers: The Case of Tarsus District of Mersin. Master Thesis, Cag University, Institute of Social Sciences, Mersin.

Kiray, A. (2011). An Empirical Study on Determining the Relationship Between Organizational Justice and Organizational Commitment. Master Thesis, Canakkale Eighteen Mart University, Canakkale.

Luthans, F. Baack, D. \& Taylor, L. (1987). Organizational Commitment: Analysis of Antecedents, Human Relations. (40), 219-236. https://doi.org/10.1177/001872678704000403

Mamedov, B. (2013). The Relationship Between Job Satisfaction and Organizational Commitment and a Research. Master Thesis, Istanbul University, Institute of Social Sciences, Istanbul.

Mathıeu, J., \& Zajac, D. M. (1990). A Review and Meta-analysis of the Antecedents Correlates and Consequences of Organizational Commitment. Psychological Bulletin. (108), 171-194. https://doi.org/10.1037/0033-2909.108.2.171

Mercan, M. (2006). Organizational Commitment, Organizational Alienation and Organizational Citizenship in Teachers Kocatepe University. Unpublished Master's Thesis, Institute of Social Sciences, Afyon.

Meyer, J. P., \& Allen, J. N. (1981). A Three-Component Conceptualization of Organizational Commitment. Human Resource Management Review. 61-89. https://doi.org/10.1016/1053-4822(91)90011-Z

Meyer, J. P., \& Allen, J. N. (1990). Affective and Continuance Commitment to the Organization: Evaluation of Measures and Analysis of Concurrent and Time-Lagged Relations. Journal of Applied Psychology. (6), 710-720. https://doi.org/10.1037/0021-9010.75.6.710

Meyer, J. P., \& Allen, J. N. (1997). Commitment to The Workplace. Theory, Research, and Application. CA: Sage Publication, United Kingdom.

Meyer, J. P., \& Allen, N. J. (1991). A Three-Component Conceptualization of Organizational Commitment. Human Resource Management Review. (1), 61-89. https://doi.org/10.1016/1053-4822(91)90011-Z

Örs, M. Acuner, A. M. Sarp, N., \& Önder, Ö. R. (2003). The Evaluation of the Opinions of Physicians and Nurses Working in Antalya Medical Faculty Hospital and Antalya State Hospital on Their Commitment to Their Organizations. Ankara University Faculty of Medicine Journal. (56), 217-224.

Oruc, M. (2013). The Relationship Between Organizational Commitment and Organizational Silence: Research in a Firm. Master Thesis, Marmara University, Institute of Social Sciences, Istanbul.

Özcan, B. (2008). The Relationship Between Organizational Commitment and Business Values: A Study in Adana Province. Master Thesis, Cukurova University, Institute of Social Sciences, Adana.

Özkaya, O., Kocakoç, İ., \& Kara, A. E. (2006). A Field Study to Investigate the Relationships between Organizational Commitment and Demographic Characteristics of Managers. Management and Economics Journal of Celal Bayar University, Faculty of Economics and Administrative Sciences. (13), 76-96.

Ozturk, M. (2013).Organizational Commitment and Organizational Commitment Levels of Health Workers. Master Thesis, Beykent University, Institute of Social Sciences, Istanbul.

Paine, S. C. (2007). The Relationship Among Interpersonel and Organizational Trustand Organizational Commitment. Ph.D. Thesis, Alliant International University.

Sage, N. (1988). Rearing of Physical Education Teachers in Turkey (Yesterday Today), Ankara University, Institute of Social Sciences. Unpublished PhD Thesis, Ankara.

Samur, S. (2018). Sport Management Information Age. Gazi Kitabevi, Ankara

Scandura, T. A., \& Lankau, M. J. (1997). Relationships of Gender, Family Responsibility and Flexible Work Hours to Organizational Commitment and Job Satisfaction. Journal of Organizational Behavior. (18), 377-391. https://doi.org/10.1002/(SICI)1099-1379(199707)18:4<377::AID-JOB807>3.0.CO;2-1

Sökmen, A. (2000). An Empirical Research on Determination of the Relationship Between Organizational Commitment and Employee Performance in Five Star Hospitality Establishments in Ankara. Unpublished Master's Thesis, Gazi University, Institute of Social Sciences, Ankara.

Steers, R. (1981). Introduction To Organizational Behavior. Goodyear Publishing Company Inc. California. 
Sunay, H. (1998). Qualifications and Training of Sports Managers Journal of Physical Education and Sports Sciences, (1), 59-68.

Sunay, H. (2009). Sports Management. Ankara: Gazi Bookstore

Suzer, H. D. (2003). Compulsory Loyalty. Capital Monthly Journal of Business and Economics, (Access): 26.11. 2011 http://www.capital.com.tr/haber.aspx?HBRiKOD=806

Tas, Ö. (2012). The Relationship Between Organizational Commitment, Organizational Trust and Job Satisfaction: An Example of a Private Hospital. Master Thesis, Ankara University, Institute of Health Sciences, Ankara.

Tinar, M. Y. (1997). Professional Socialization and Personality. Dokuz Eylül University Journal of the Faculty of Economics and Administrative Sciences. (12), 114.

Uygur, A. (2004). Organizational Commitment and Employee Performance'. Foundations Bank of Turkey in Ankara, Istanbul and Izmir Province Branch of the Field Research., Unpublished PhD Thesis., Hacettepe University, Institute of Social Sciences, Ankara.

Yalçın, A., \& İplik, F. N. (2005). A Study on Determining Factors Affecting Organizational Commitment of Employees in Group A Travel Agencies: The Case of Adana, Selçuk University Journal of the Institute of Social Sciences. (18), 486-500.

Yang, J. (2005). The Role of Trust in Organizations: Do Foci and Bases Matter. The Interdepartmental Program in Business Administration (Management), Nanjing University, China.

Yetim, A. (1996). Leadership in Sport Management, Journal of Physical Education and Sport Sciences Sports, (3), 85-94.

Yıldiz, K. (2013). The Relationship Between Organizational Commitment and Organizational Cynicism and Organizational Opposition, International Periodical For The Languages, Literature and History of Turkish or Turkic. 853-879.

Zaman, M. (2000). Leading Leadership in Developing Your Team's Capabilities. İstanbul: Hayat

\section{Copyrights}

Copyright for this article is retained by the author(s), with first publication rights granted to the journal.

This is an open-access article distributed under the terms and conditions of the Creative Commons Attribution license which permits unrestricted use, distribution, and reproduction in any medium, provided the original work is properly cited. 